Original Research Paper

\title{
An Effective and Viable DNA Extraction Protocol for FFPE Tissues and its Effect on Downstream Molecular Application
} \author{
Mohanapriya, ${ }^{1}$ Nirmala Karuppasamy, ${ }^{1}$ Zioni Sangeetha Shankaran and ${ }^{3}$ Thanka Johnson \\ ${ }^{1}$ Department of Biotechnology, Sri Ramachandra Institute of Higher Education and Research \\ (Formerly Sri Ramachandra Medical College and Research Institute), Chennai, India \\ ${ }^{2}$ Central Research Facility, Sri Ramachandra Institute of Higher Education and Research \\ (Formerly Sri Ramachandra Medical College and Research Institute), Chennai, India \\ ${ }^{3}$ Department of Pathology, Sri Ramachandra Institute of Higher Education and Research \\ (Formerly Sri Ramachandra Medical College and Research Institute), Chennai, India
}

1,*Sai Sushmitha Kontham, ${ }^{1, *}$ Charles Emmanuel Jebaraj Walter, ${ }^{1}$ Manjula Raju, ${ }^{2}$ Chinambedu Dandapani

\section{Article history}

Received: $10-01-2020$

Revised: 19-02-2020

Accepted: 21-03-2020

Corresponding Author: Charles Emmanuel Jebaraj Walter

Department of Biotechnology, Sri Ramachandra Institute of Higher Education and Research (Formerly Sri Ramachandra Medical College and Research Institute), Chennai, India Email: cejwalter@sriramachandra.edu.in

*These authors contributed equally

\begin{abstract}
Archival Formalin-Fixed Paraffin-Embedded (FFPE) tissues are a readily available source of DNA for retrospective studies including genetic predisposition. FFPE tissues present significant challenges for extraction of pure genomic DNA in adequate amounts due to the harsh fixation conditions and long-term storage associated with samples. The aim of the study is to propose a simple, in-expensive, viable protocol for the extraction of DNA from FFPE tissues and to optimize the same for the detection of 3'UTR miRNA binding site polymorphism in ADAMTS1 gene in colorectal cancer tissues and normal colonic mucosa archival tissues using Sanger sequencing and TaqMan SNP genotyping assay. Five different DNA extraction methods were compared and analyzed. NanoDrop quantification demonstrated that out of the various methods tested, highest quantity and pure DNA was obtained from Modified non heating extraction. When we further applied this method for colorectal cancer tissues and normal colonic mucosa archival tissues the NanoDrop readout indicated that the DNA was intact and pure. Intra samples comparison over a time period of 6 months revealed that the DNA was intact. The samples isolated with Modified non heating extraction were found suitable for downstream processes such as Sanger sequencing and TaqMan SNP genotyping assay. This cost effective and non-arduous protocol can successfully extract even minute quantities of DNA from FFPE tissues and facilitate the downstream molecular analysis of a large number of archival specimens for retrospective studies.
\end{abstract}

Keywords: FFPE Tissues, Sanger Sequencing, Colorectal Cancer, Modified Non Heating Extraction, TaqMan SNP Genotyping Assay

\section{Introduction}

Worldwide FFPE tissues are archived in hospitals and tissue banks to serve as an important source of knowledge on genetic and pathological events involved in various aspects of clinical conditions (Blow, 2007). In the last decade there have been exceptional advancements in the field of molecular pathology, providing avenues to deduce molecular mechanisms; screen and evaluate biomarkers pertaining to a variety of diseases. Today these samples present both an incredible opportunity and an immense challenge to researchers. FFPE tissues have been extensively annotated and well preserved, allowing an in depth study of the development of disease such as Mycobacterium tuberculosis and tumor progression. Formalin fixation and paraffin embedding have been the clinical gold standard for preserving these precious samples (Lehmann and Kreipe, 2001; Gnanapragasam, 2010). FFPE tissues have numerous advantages compared to fresh or frozen tissues; they can be effortlessly handled and are inexpensive long-term storage materials which are valuable in various aspects (Ludyga et al., 2012). They are stable at ambient temperature, can be easily stored and do not require specialized amenities. FFPE tissue samples can be used for retrospective studies; these sections exhibit various histological features of cancer, including precancerous lesions and facilitate 
evaluation of the genetic events correlated to the observed histological changes (Einaga et al., 2017).

Of late FFPE tissue specimens have shown compatibility with diverse analytical tools, such as isotope labeling, affinity enrichment and Laser Capture Micro dissection (LCM), increasing the viability of utilizing these tissues as a substitute to frozen tissues for retrospective and prospective protein biomarker discovery (Xiao et al., 2010; Toews et al., 2008; Azimzadeh et al., 2010; Wisniewski et al., 2011). In contrast, frozen tissues require specialized facilities for storage, which makes handling outside the research setting challenging, predominantly due to the possibility of rapid decaying. Despite the fact that FFPE tissue is often considered as one of the best choices for clinical molecular applications, isolation of DNA from FFPE tissues is a tedious task. Different protocols have been followed to extract DNA from FFPE tissues for molecular analysis. It is well known that PCR is very difficult to perform with DNA extracted from fixed tissues and fixation intervals are the main reason for decreased PCR yields and incapability to amplify longer DNA targets (Quach et al., 2004). It has been previously reported that only up to 300 bp of DNA was amplifiable from FFPE postmortem tissues and more often amplicon size up to $100 \mathrm{bp}$ had given consistent PCR results (Bonin et al., 2003). Many studies have been done to optimize the extraction of DNA from FFPE tissues. Among the existing protocols, use of mineral oil for deparaffinization (Lin et al., 2009) and the use of high-temperatures with $0.1 \mathrm{M} \mathrm{NaOH}$ have shown to increase the efficiency of DNA extraction by manual methods (Pikor et al., 2011; Shi et al., 2004). Besides, a variety of commercial kits (Huijsmans et al., 2010) and have likewise been utilized for DNA extraction.

FFPE tissues have been used for downstream molecular analysis, such as real-time quantitative PCR, Next generation sequencing, Whole genome sequencing, Sanger sequencing and TaqMan SNP genotyping assay. Amongst these, TaqMan SNP genotyping assay is an ideal option for the analysis of cancer markers which can be performed on small copy targets and on degraded DNA due to its increased sensitivity and specificity for the DNA extracted from FFPE tissues. Sanger sequencing has been considered the gold standard for identifying single nucleotide polymorphisms in FFPE tissues for a long time because of its low false-positive rate and high specificity.

A Disintegrin And Metalloproteinase (ADAM) represents a protein family possessing both metalloproteinase and disintegrin domains. ADAMTS-1 is a member of the ADAM protein family which is involved in proteolytic modification of cell-surface proteins and extracellular matrices (Shindo et al., 2000). The unique structure of ADAMTS-1, characterized by the presence of thrombospondin type I motifs and is shared by other newly identified proteins in mammals and in C. elegans, which comprise the ADAMTS subfamily that may perform well-conserved biological functions. ADAMTS-1 was originally identified by differential display analysis as a gene highly expressed in the murine colon 26 cachexigenic tumors (Kuno et al., 1997). In vivo expression of the gene induced in the kidney and heart of mice treated with lipopolysaccharide, suggested a potential role of ADAMTS-1 in the inflammatory reactions (Kuno et al., 1997).

This study aims to (1) develop an efficient method for DNA isolation to obtain optimum DNA concentration and purity from FFPE tissues. (2) To optimize a protocol for the detection of 3'UTR miRNA binding site polymorphism in ADAMTS1 gene in colorectal cancer tissues normal colonic mucosa archival tissues using Sanger sequencing and TaqMan SNP genotyping assay. Different isolation methods that were compared include Modified non heating extraction, Spin column extraction, Non heating extraction, Salting-out method and Phenol chloroform extraction.

\section{Materials and Methods}

\section{Tissue Selection and Processing}

Formalin-fixed paraffin-embedded colon cancer and normal colonic mucosa tissues (non cancerous tissues) were obtained from the pathology archives of Sri Ramachandra Medical College \& Research Institute after due Institutional Ethical clearance (REF:IECNI/15/APR/46/26). A total of 50 FFPE tissues were utilized for the study. The tissues fixed in $10 \%$ buffered formalin at ambient conditions were embedded and used. Twenty micron sections were cut utilizing a standard microtome (Shi et al., 2002) and the slices were taken into a sterile $1.5 \mathrm{~mL}$ micro centrifuge tube directly.

\section{Deparaffinization and Tissue Digestion}

The tissues were heated at $55-58^{\circ} \mathrm{C}$ for five $\min$. Subsequently the sections were deparaffinized with $100 \%$ xylene twice and incubated at $56^{\circ} \mathrm{C}$ for five min, vortexed for $2 \mathrm{~min}$ and centrifuged at 13,000 rpm for ten min at ambient conditions. This was followed by subjecting it to $100 \%, 75 \%$ and $50 \%$ ethanol washes and centrifugation at 13,000 rpm (Pikor et al., 2011; Goelz et al., 1985). The tissue pellets were dried free of ethanol at $37^{\circ} \mathrm{C}$.

\section{DNA Isolation}

DNA was extracted from FFPE tissues using Modified non heating extraction, Spin column extraction, Non heating extraction, Salting-out method and phenol chloroform extraction. A brief outline of the DNA extraction protocols is shown in Table 1. A pictorial representation of the various methods involved in the study is shown in Fig. 1. 


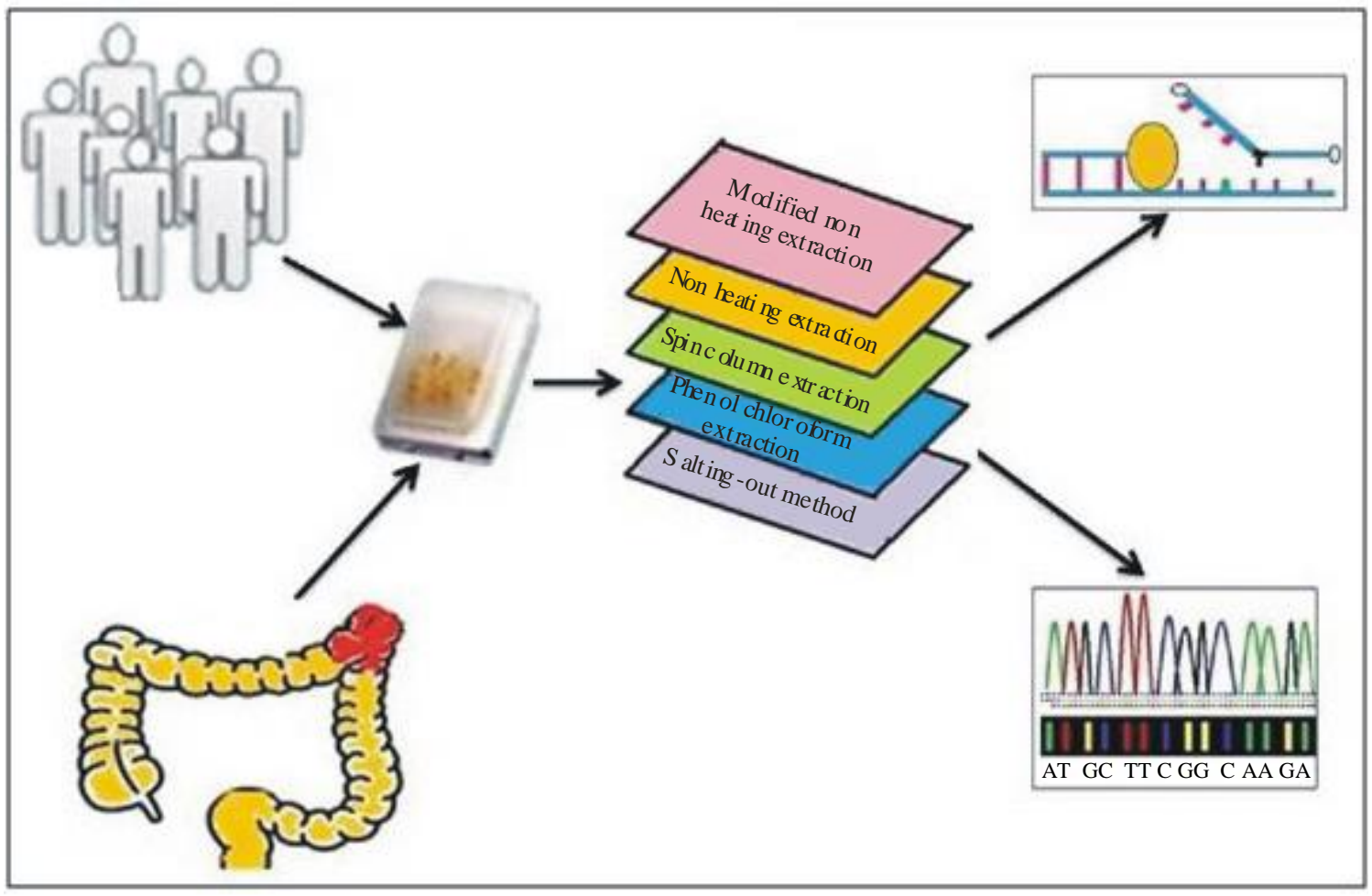

Fig. 1: Overview of the various extraction methods using FFPE tissues

Table 1: Outline of the DNA extraction protocols

\begin{tabular}{|c|c|c|c|c|c|}
\hline Extraction method & $\begin{array}{l}\text { Modified non } \\
\text { heating extraction }\end{array}$ & $\begin{array}{l}\text { Spin column } \\
\text { extraction }\end{array}$ & $\begin{array}{l}\text { Non heating } \\
\text { extraction }\end{array}$ & $\begin{array}{l}\text { Salting-out } \\
\text { method }\end{array}$ & $\begin{array}{l}\text { Phenol chloroform } \\
\text { method }\end{array}$ \\
\hline Column based & No & Yes & No & No & No \\
\hline Trimming excess paraffin & Yes & No & No & No & No \\
\hline Deparaffinization & $\begin{array}{l}\text { Ethanol and } \\
\text { xylene }\end{array}$ & $\begin{array}{l}\text { Ethanol and } \\
\text { xylene }\end{array}$ & $\begin{array}{l}\text { Ethanol and } \\
\text { xylene }\end{array}$ & $\begin{array}{l}\text { Ethanol and } \\
\text { xylene }\end{array}$ & $\begin{array}{l}\text { Ethanol and } \\
\text { xylene }\end{array}$ \\
\hline \multirow[t]{2}{*}{ Tissue Digestion } & Digestion buffer & ATL buffer & Lysis buffer & Lysis buffer & Digestion buffer \\
\hline & Proteinase $\mathrm{K}$ & Proteinase $\mathrm{K}$ & Proteinase $\mathrm{K}$ & Proteinase K & Proteinase K \\
\hline Digestion conditions & $56^{\circ} \mathrm{C}$ over night & $56^{\circ} \mathrm{C} 1 \mathrm{~h}$ & $52^{\circ} \mathrm{C}$ over night & $55^{\circ} \mathrm{C}$ over night & $55^{\circ} \mathrm{C}$ over night \\
\hline Extraction & PCI & GB buffer & PCI & PCI & PCI \\
\hline Precipitation & $\begin{array}{l}\text { Sodium acetate } \\
\text { and ethanol }\end{array}$ & - & $\begin{array}{l}\text { Sodium acetate } \\
\text { and isopropanol }\end{array}$ & $\begin{array}{l}\text { Absolute } \\
\text { alcohol }\end{array}$ & Isopropanol \\
\hline Elution buffer & TE Buffer & ATE buffer & Distilled water & $70 \%$ ethanol & $70 \%$ ethanol \\
\hline Final elution volume & $40 \mu \mathrm{L}$ & $100 \mu \mathrm{L}$ & $50 \mu \mathrm{L}$ & $30 \mu \mathrm{L}$ TE buffer & $40 \mu \mathrm{L}$ MilliQ water \\
\hline Special conditions & $\begin{array}{l}\text { Pre heat elution buffer } \\
\text { at } 95^{\circ} \mathrm{C} \text { for } 10 \mathrm{~min} \text {, } \\
\text { heat the samples at } \\
65^{\circ} \mathrm{C} \text { after eluting in } \\
\mathrm{TE} \text { buffer }\end{array}$ & - & - & - & - \\
\hline
\end{tabular}

TE, Tris EDTA, PCI, Phenol chloroform isoamyl alcohol

\section{Modified Non Heating Extraction}

Excess paraffin from the tissues was trimmed and the tissues were deparaffinized as mentioned above and PBS was added in two changes after which 500 $\mu \mathrm{L}$ of lysis buffer (proteinase $\mathrm{K} 20 \mathrm{mg} / \mathrm{ml} 50 \mu \mathrm{L}, 1 \mathrm{M}$ Tris- $\mathrm{HCl}$ solution $10 \mu \mathrm{L}, 0.5 \mathrm{M}$ EDTA $2 \mu \mathrm{L}, 10 \%$
SDS $100 \mu \mathrm{L}$ and distilled water $838 \mu \mathrm{L}$ ) was added and incubated at $56^{\circ} \mathrm{C}$ overnight until all tissue fragments were dissolved completely. Extraction and purification were performed by adding $500 \mu \mathrm{L}$ of 25:24:1 phenol: Chloroform: Isoamyl alcohol to the dewaxed tissue, followed by vortexing (cyclo mixer) and centrifugation at RT, 12,000 g for $10 \mathrm{~min}$. The 
upper aqueous supernatant was transferred to a new micro centrifuge tube and one volume of chloroform was added, vortexed and was centrifuged at 12,000 $\mathrm{g}$ for $10 \mathrm{~min}$. The upper aqueous supernatant was transferred into a new micro centrifuge tube, 0.1 volume of $3 \mathrm{M}$ sodium acetate was added, vortexed after which one volume of ethanol was added and incubated at $-20^{\circ} \mathrm{C}$ overnight. The precipitated DNA was centrifuged at $12,000 \mathrm{~g}$ at $4^{\circ} \mathrm{C}$ for $10 \mathrm{~min}$. The supernatant was discarded and the precipitate was washed twice with $75 \%$ ethanol (Shi et al., 2004). The pellet was dried free of ethanol and was dissolved in $40 \mu \mathrm{L}$ of preheated (heated at $95^{\circ} \mathrm{C}$ for $10 \mathrm{~min}$ ) $\mathrm{TE}$ buffer. And the eluted DNA was again heated at $65^{\circ} \mathrm{C}$ for five $\min$.

\section{Spin Column Extraction}

The commercial spin column DNA extraction was performed according to the manufacturer's instructions. The tissues were deparaffinized with xylene, followed by two washes with $100 \%$ ethanol to remove remaining xylene. After deparaffinization, tissues were digested at $56^{\circ} \mathrm{C}$ with $180 \mu \mathrm{L}$ of ATL buffer and $20 \mu \mathrm{L}$ proteinase $\mathrm{K}$. The completely digested tissues were incubated at $90^{\circ} \mathrm{C}$ for $1 \mathrm{~h}$. Subsequent to digestion, $200 \mu \mathrm{L}$ of $\mathrm{AL}$ buffer was added, followed by ethanol precipitation. The solution was transferred into a new spin column and washed with wash buffers AW1 and AW2 provided in the kit. The DNA was eluted in $40 \mu \mathrm{L}$ ATE buffer.

\section{Non Heating Extraction Method}

Tissues were deparaffinized as mentioned above and PBS was added in two changes after which 500 $\mu \mathrm{L}$ of lysis buffer (proteinase K $20 \mathrm{mg} / \mathrm{ml}, 50 \mu \mathrm{L}, 1 \mathrm{M}$ Tris-HCl solution $10 \mu \mathrm{L}, 0.5 \mathrm{M}$ EDTA $2 \mu \mathrm{L}, 10 \%$ SDS $100 \mu \mathrm{L}$ and distilled water $838 \mu \mathrm{L}$ ) was added and incubated at $52^{\circ} \mathrm{C}$ overnight until all tissue fragments were dissolved completely. Extraction and purification was performed by adding $500 \mu \mathrm{L}$ of 25:24:1 phenol: Chloroform: Isopropanol alcohol to the dewaxed tissue, followed by vortexing (cyclo mixer) and centrifugation at $12,000 \mathrm{~g}$ for $10 \mathrm{~min}$. The upper aqueous supernatant was transferred to a new micro centrifuge tube after which one volume of chloroform was added, vortexed and was centrifuged at $12,000 \mathrm{~g}$ for $10 \mathrm{~min}$. The upper aqueous supernatant was transferred into a new micro centrifuge tube, 0.1 volume of $3 \mathrm{M}$ sodium acetate was added vortexed after which one volume of isopropanol was added and incubated at $-20^{\circ} \mathrm{C}$ overnight. The precipitated DNA was centrifuged at $12,000 \mathrm{~g}$ at $4^{\circ} \mathrm{C}$ for $10 \mathrm{~min}$. The supernatant was discarded and the precipitate was washed twice with $75 \%$ ethanol (Shi et al., 2004). The pellet was dried free of ethanol and was dissolved in $50 \mu \mathrm{L}$ double distilled water.

\section{Salting-Out Method}

Tissues were deparaffinized as mentioned above. One $\mathrm{mL}$ of lysis buffer solution was added along with $50 \mu \mathrm{L}$ of $10 \%$ SDS and inverted for $10 \mathrm{~min}$. To this mixture, $6 \mathrm{M} \mathrm{NaCl}$ was added and incubated overnight. This was followed by centrifugation at $3000 \mathrm{rpm}$ for $20 \mathrm{~min}$. Supernatant was collected; to this double the volume of chilled $100 \%$ ethanol was added. The DNA was transferred into a new micro centrifuge tube and centrifuged at $12,000 \mathrm{rpm}$ for 10 min at ambient conditions (Miller et al., 1988). Supernatant was disposed and $1 \mathrm{~mL}$ of $70 \%$ ethanol was added and centrifuged at $12,000 \mathrm{rpm}$ at $4{ }^{\circ} \mathrm{C}$. The pellet was dried free of ethanol, after which $30 \mu \mathrm{L}$ of TE buffer was added to dissolve the pellet.

\section{Phenol Chloroform Extraction}

After deparaffinization as described above the pellet was dried at $37^{\circ} \mathrm{C}$. Dried tissue was dissolved in $300 \mu \mathrm{L}$ of digestion buffer containing $50 \mathrm{mM}$ Tris, 5 $\mathrm{mM}$ EDTA, $\mathrm{pH} 8$ and $10 \mu \mathrm{g} / \mathrm{ml}$ proteinase $\mathrm{K}$. Subsequent to overnight incubation at $56^{\circ} \mathrm{C}$, the digested tissue was centrifuged with phenol chloroform. The upper aqueous layer was taken and the DNA was precipitated overnight with sodium acetate and ethanol. Centrifugation was done for 30 $\min$ at $4^{\circ} \mathrm{C}$, the pellet formed was washed with $1 \mathrm{~mL}$ of $70 \%$ ethanol and was air dried at ambient conditions (Dedhia et al., 2007). Later the DNA was eluted in $40 \mu \mathrm{L}$ of miliQ water.

\section{Quality Assessment of DNA}

After the completion of DNA isolation, $3 \mu \mathrm{L}$ DNA was subjected to $0.8 \%$ agarose gel electrophoresis to check the presence of intact DNA. Comparison of the quality of FFPE tissue DNA isolated using five different isolation methods is shown in Fig. 2A. The yield was compared between five Different isolation methods by using NanoDropTM 1000 spectrophotometer. This was measured according to the standard protocol recommended by the manufacturer. Further FFPE tissues from the year 2011-2017 was subjected to Modified non heating extraction and checked for purity and stability of the DNA. Also NanoDrop quantification was done in 3 months and 6 months interval to follow up the DNA stability. The quantified DNA was subjected to Sanger sequencing and TaqMan SNP genotyping assay. 


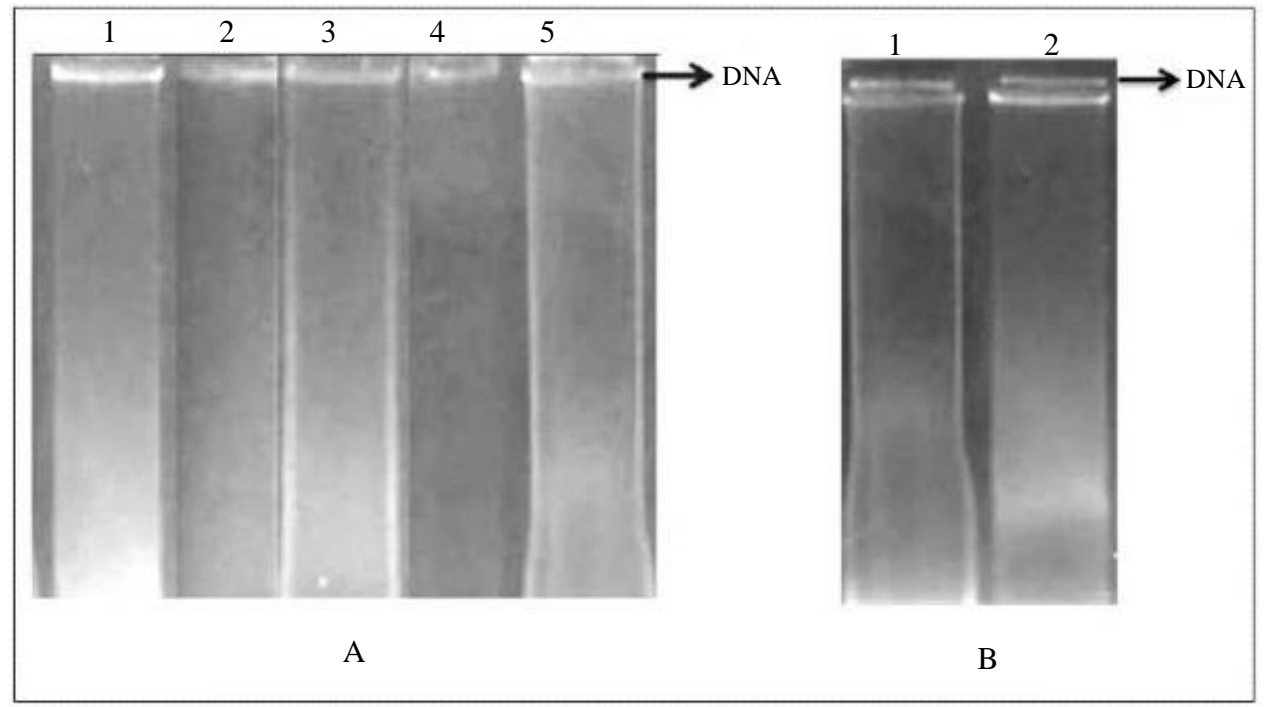

Fig. 2: An Agarose gel electrophoresis of DNA isolated from FFPE tissues using five different methods. Lane 1: Modified non heating extraction method, Lane 2: Spin column extraction, Lane 3: Non heating extraction method, Lane 4: Salting-out method, Lane 5

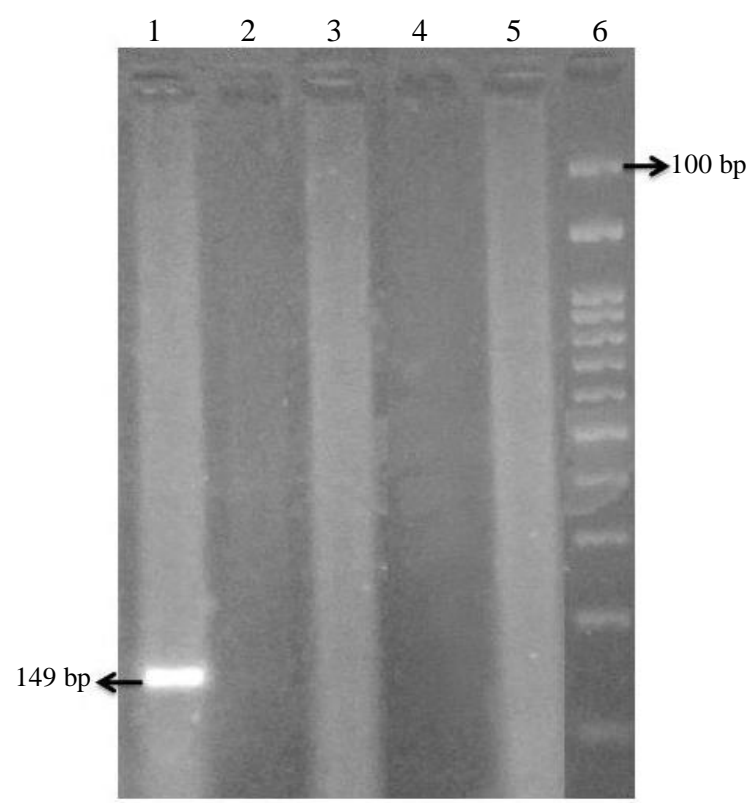

Fig. 3: Agarose gel electrophoresis of PCR product obtained from FFPE tissue DNA extracted by different methods. Lane 1: Modified non heating extraction method, Lane 2: Spin column extraction, Lane 3: Non heating extraction method, Lane: Salting -out metho

\section{PCR Amplification}

DNA extracted from five different extraction methods was used for performing PCR. PCR amplification was observed from the DNA isolated from Modified non heating extraction (Fig. 3). Further, this DNA was used for Sanger sequencing. 2 $\mu \mathrm{L}$ of $50 \mathrm{ng}$ DNA template was added to PCR master mix containing $5 \mathrm{U}$ Taq polymerase, $2 \mathrm{mM}$ dNTPs, 5 pmol forward and reverse primer (Table 2), 10X buffer and double distilled water. The PCR reaction was carried out with a 4 min initial denaturation at $94^{\circ} \mathrm{C}$, denaturation for $30 \mathrm{sec}$ at $94^{\circ} \mathrm{C}$, annealing for $30 \mathrm{sec}$ at $56.4^{\circ} \mathrm{C}$, extension for $30 \mathrm{sec}$ at $72^{\circ} \mathrm{C}$ and final extension for $30 \mathrm{sec}$ at $72^{\circ} \mathrm{C}$ for 35 cycles, followed by storage at $4^{\circ} \mathrm{C} .10 \mu \mathrm{L}$ of PCR products were resolved on a $2 \%$ agarose gel.

\section{PCR Optimization}

FFPE tissue DNA extracted from colon cancer tissue and normal colonic mucosa using Modified non heating extraction method was utilized for PCR optimization. ADAMTS1 gene was amplified using forward and reverse primer (Table 2). Annealing temperature, primer concentration and template quantity were standardized. Annealing temperatures tried were $54.6^{\circ} \mathrm{C}, 54.8^{\circ} \mathrm{C}, 55.4^{\circ} \mathrm{C}, 56.4^{\circ} \mathrm{C}, 58.0^{\circ} \mathrm{C}$, $59.1^{\circ} \mathrm{C}$ and $59.7^{\circ} \mathrm{C}$. Two different primer concentrations of $10 \mathrm{pmol}, 5 \mathrm{pmol}$ were tried, avoiding primer dimer formation was considered as a primary factor during optimization of primer concentration. Template concentrations of $100 \mathrm{ng}, 50$ $\mathrm{ng}, 250 \mathrm{ng}$ and undiluted DNA were used. The reaction volume was $20 \mu \mathrm{L}$, which consisted of master mix, template DNA, forward and reverse primer. No template control was also included for the reaction. 
Table 2: Primer details

\begin{tabular}{llll}
\hline Name of the gene & Tm & Product size & Sequence $\left(5^{\prime}-3^{\prime}\right)$ \\
\hline ADAMTS1-Forward primer & $56.4^{\circ} \mathrm{C}$ & $218 \mathrm{bp}$ & GTATCATGGGGGTTGGGAA \\
ADAMTS1-Reverse primer & $56.4^{\circ} \mathrm{C}$ & $218 \mathrm{bp}$ & CGTTGCTGAGCCTTTCTCTC \\
\hline
\end{tabular}

$T m$, primer melting Temperature, $b p$, base pair

\section{Sanger Sequencing}

The amplified products were subjected to Sanger sequencing using Big Dye Terminator V.3.1. (Applied Biosystems, Foster City, CA) in ABI Prism ${ }^{\mathrm{TM}} 3730$ Genetic Analyzer (Applied Biosystems, Foster City, CA). Sequences were evaluated with SeqScape analysis software V2.5.

\section{Allelic Discrimination by TaqMan SNP Genotyping Assay}

The allelic discrimination by TaqMan SNP genotyping assay was carried out in Fast 7900 HT Real Time PCR machine using DNA extracted from Modified non heating extraction. PCR was performed in a $5 \mu \mathrm{L}$ reaction mixture containing $1 \mu \mathrm{L}$ of $50 \mathrm{ng}$ DNA, $2.5 \mu \mathrm{L}$ TaqMan Genotyping Master mix, 0.1 $\mu \mathrm{L}$ TaqMan SNP genotyping assay Mix and $1.4 \mu \mathrm{L}$ of water. The PCR conditions used were: Stage I: $50^{\circ} \mathrm{C}$ for 2 min Stage II: $95^{\circ} \mathrm{C}$ for $10 \mathrm{~min}$ Stage III: $95^{\circ} \mathrm{C}$ for $15 \mathrm{sec}$ and $60^{\circ} \mathrm{C}$ for 1 min for forty cycles. Genotype identification was performed using Sequence Detection Software 2.0 (SDS).

\section{Optimization of Allelic Discrimination by TaqMan} SNP Genotyping Assay

TaqMan SNP genotyping assay was performed on DNA isolated from colon cancer FFPE tissues and normal colonic mucosa samples using the Modified non heating extraction. The concentration of DNA and quantity of master mix was standardized. Template concentrations of $50 \mathrm{ng}$, undiluted DNA, $2.5 \mu \mathrm{L}, 2.75 \mu \mathrm{L}$ and $3.0 \mu \mathrm{L}$ of master mix were used for standardization. The reaction volume was $5 \mu \mathrm{L}$, which consisted of Taqman Genotyping Master Mix, TaqMan SNP genotyping assay Mix, water and template DNA. No template control was also included.

\section{Statistical Analysis}

The statistical analysis was performed using SPSS software version 20.0. Student's t-test was done to compare the difference between concentrations of DNA obtained from five different extraction methods. $\mathrm{P}$ values below 0.05 were acknowledged as significant.

\section{Results}

\section{FFPE Tissue DNA Extraction}

Four diverse DNA extraction protocols along with one modified DNA extraction protocol were carried out in parallel to assess the yield and quality of DNA isolated from FFPE tissue samples. Maximum yield was observed in the range of 500-2500 $\mu \mathrm{g}$ which was obtained with Modified non heating extraction and minimum yield was seen in the range of $7 \mu \mathrm{g}-20 \mu \mathrm{g}$ which was obtained by Spin column extraction method as shown in Table 3. The maximum purity of DNA obtained at OD 260/280 was 1.9 which was observed in Modified non heating extraction. The quantity of DNA obtained using Modified non heating extraction protocol was good enough for optimization of Sanger sequencing and TaqMan SNP genotyping assay. Among the five different methods, significant results in terms of concentration, were obtained from the samples treated with the Modified non heating extraction $(p=0.0002)$ compared to the samples that were isolated with the Spin column extraction. Furthermore, the samples isolated with Modified non heating treatment produced remarkably significantly pure DNA compared to Saltingout and Phenol chloroform method (Table 3).

Student's $t$-test was performed to compare the DNA concentrations between the five different isolation methods, where Spin column extraction method was considered as the reference method. The results were significant where $p$ value was less than 0.05 . Further FFPE tissues from the year 2011-2017 was subjected to Modified non heating extraction and checked for purity and stability of the DNA. Also, NanoDrop quantification was done in 3 months and 6 months intervals to follow up the DNA stability most importantly; year-wise comparison of the NanoDrop reading also suggested that this method results in good quality and quantity of DNA. FFPE tissues collected from 2011 archive yielded 1091 ng of DNA and the highest of $2480 \mathrm{ng}$ was obtained from FFPE tissues belonging to 2017 archive (Table 4 and Fig. 4). When intra sample NanoDrop comparison was done after three months and six months respectively, the DNA had minimal degradation and was intact to perform downstream molecular applications (Table 4 and Fig. 5). The NanoDrop reading for the colorectal cancer tissues and normal colonic mucosa tissues (non cancerous tissues) indicate that good quantity of intact DNA can be isolated by using Modified non heating extraction method (Table 4). However the quantity of DNA obtained from normal colonic mucosa tissues was lesser compared to colorectal cancer tissues. The primary reason for this was the size of the biopsy. But it was observed that the DNA obtained from normal colonic mucosa was stable, pure and was suitable for performing Sanger sequencing and TaqMan SNP genotyping assay. 
Table 3: Quantity and quality of DNA extracted from formalin fixed paraffin embedded tissues

\begin{tabular}{llll}
\hline Extraction method & Mean $\pm \mathrm{SD}($ Concentration $\mathrm{ng} / \mu \mathrm{L})$ & $\mathrm{P}$ value & A260/280 \\
\hline Modified non heating extraction & $1619.51 \pm 1012.97$ & 0.0002 & $1.8-1.9$ \\
Spin column extraction & $101.5 \pm 69.39$ & (reference) & $1.8-1.9$ \\
Non heating extraction & $1078.16 \pm 704.69$ & 0.0004 & $1.8-1.9$ \\
Salting-out method & $38.53 \pm 28.55$ & 0.0161 & $1.4-1.7$ \\
Phenol chloroform method & $152.1 \pm 158.99$ & 0.3687 & $1.4-1.9$ \\
\hline
\end{tabular}

Bold values are significant, SD, Standard deviation; Student's $t$-test was done to compare the DNA concentrations between the five different isolation methods. The results are considered significant where $\mathrm{P}$ value was less than 0.05

Table 4: Comparison of DNA quality and quantity post 3 and 6 months of DNA isolation among samples from different time period

\begin{tabular}{|c|c|c|c|c|c|c|}
\hline Sample No & Tissue Thickness & Year & A260/280 & Initial values $n g / \mu \mathrm{L}$ & values after 3 months $\mathrm{ng} / \mu \mathrm{L}$ & values after 6 months $\mathrm{ng} / \mu \mathrm{L}$ \\
\hline CA-18/17 & 60 micron & 2017 & 1.9 & 2480 & 2440 & 2400 \\
\hline CON-15/17 & 60 micron & 2017 & 1.9 & 220 & 210 & 195 \\
\hline CA-37/17 & 60 micron & 2017 & 1.8 & 974 & 960 & 945 \\
\hline CA-12/16 & 60 micron & 2016 & 1.9 & 2376 & 2356 & 2340 \\
\hline CON-41/16 & 60 micron & 2016 & 1.9 & 352 & 340 & 332 \\
\hline CA-58/16 & 60 micron & 2016 & 1.9 & 1663 & 1640 & 1630 \\
\hline CA-33/15 & 60 micron & 2015 & 1.9 & 1312 & 1280 & 1240 \\
\hline CON-64/15 & 60 micron & 2015 & 1.9 & 253 & 240 & 225 \\
\hline CA-25/15 & 60 micron & 2015 & 1.8 & 2340 & 2320 & 2300 \\
\hline CA-17/14 & 60 micron & 2014 & 1.8 & 1604 & 1580 & 1560 \\
\hline CON-60/14 & 60 micron & 2014 & 1.8 & 476 & 460 & 440 \\
\hline CA-30/14 & 60 micron & 2014 & 1.9 & 1841 & 1820 & 1800 \\
\hline CA-48/13 & 60 micron & 2013 & 1.8 & 1091 & 1050 & 1000 \\
\hline CON-33/13 & 60 micron & 2013 & 1.9 & 374 & 360 & 345 \\
\hline CA-77/13 & 60 micron & 2013 & 1.8 & 1897 & 1870 & 1855 \\
\hline CA-11/12 & 60 micron & 2012 & 1.8 & 1755 & 1740 & 1700 \\
\hline CON-16/12 & 60 micron & 2012 & 1.8 & 481 & 465 & 440 \\
\hline CA-30/12 & 60 micron & 2012 & 1.9 & 1841 & 1820 & 1800 \\
\hline CA-19/11 & 60 micron & 2011 & 1.8 & 1091 & 1050 & 1000 \\
\hline CON-35/11 & 60 micron & 2011 & 1.8 & 351 & 333 & 315 \\
\hline CA-84/11 & 60 micron & 2011 & 1.8 & 2688 & 2650 & 2632 \\
\hline
\end{tabular}

ng, nanogram, CA, Colorectal cancer tissues, CON, Normal colonic mucosa tissues

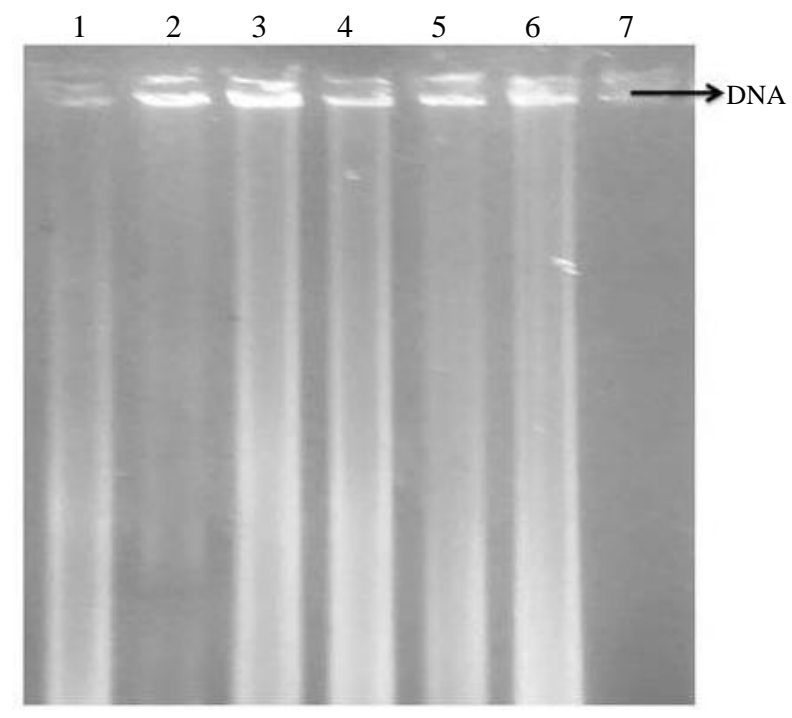

Fig. 4: Agarose gel electrophoresis of DNA isolated from FFPE tissues using Modified non heating extraction. Lane 1: 2011, Lane 2: 2012, Lane 3: 2013, Lane 4: 2014, Lane 5: 2015, Lane 6: 2016, Lane 7: 2017

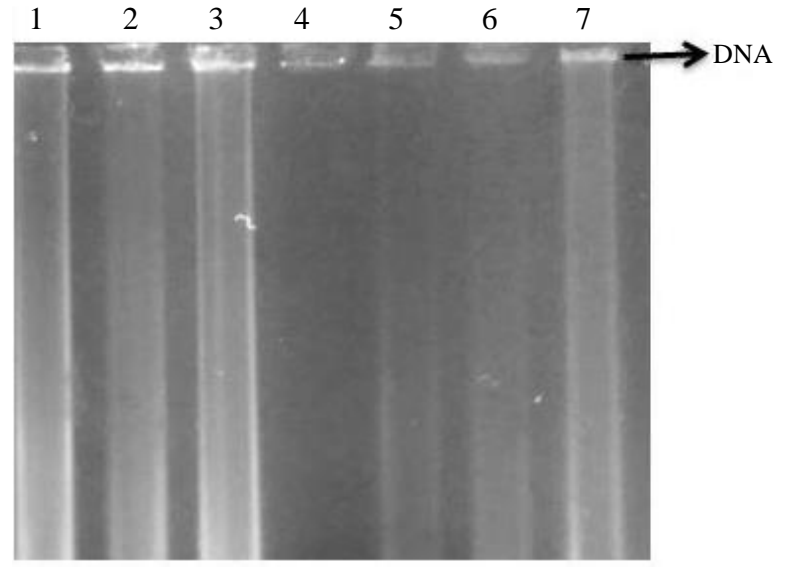

Fig. 5: Agarose gel electrophoresis of FFPE tissue DNA to compare stability of DNA after 6 months of isolation and storage. Lane 1: 2011, Lane 2: 2012, Lane 3: 2013, Lane 4: 2014, Lane 5: 2015, Lane 6: 2016, Lane 7: 2017

\section{PCR Amplification and Optimization}

Among the five different DNA extraction protocols, DNA extracted through Modified non heating extraction 
method showed proper PCR amplification compared to other four methods (Fig. 3). PCR results indicated a prominent band in the range of 218 bp (Fig. 6). In case of ADAMTS1 gene amplification, commendable results were acquired at an annealing temperature of $56.4^{\circ} \mathrm{C}$. Primer concentration of 5 pmol was used for better results and primer dimmers were not observed. PCR amplification was visible only with $50 \mathrm{ng}$ of DNA. While $100 \mathrm{ng}, 250 \mathrm{ng}$ and undiluted DNA samples failed to demonstrate any amplification.

\section{Allelic Discrimination by TaqMan SNP Genotyping Assay}

Template concentration of $50 \mathrm{ng}$ and $2.5 \mu \mathrm{L}$ master mix showed good genotyping results. Automatic calling was performed to analyze the results obtained from the Sequence detection systems software. The results of the allelic discrimination assay data were plotted as Allele 1 (VICTM dye) versus Allele 2 $\left(\mathrm{FAM}^{\mathrm{TM}}\right.$ dye).

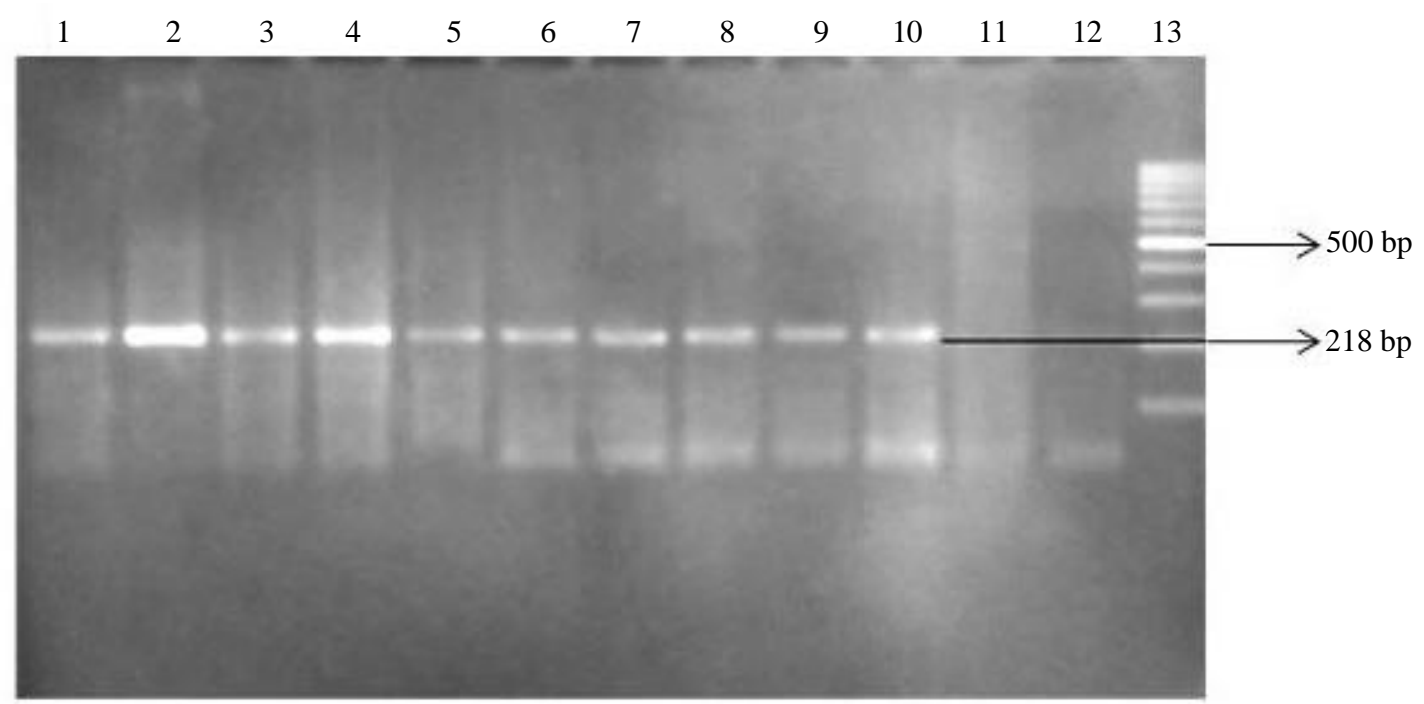

Fig. 6: Agarose gel electrophoresis of PCR products obtained from ADAMTS1 gene amplification using FFPE tissue DNA isolated from Modified non heating extraction (218 bp). Lane 1-6: Genomic DNA isolated from representative colorectal cancer tissues. Lane 7

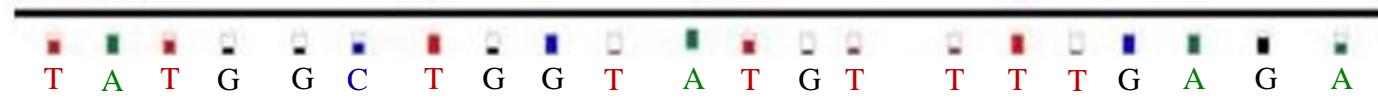

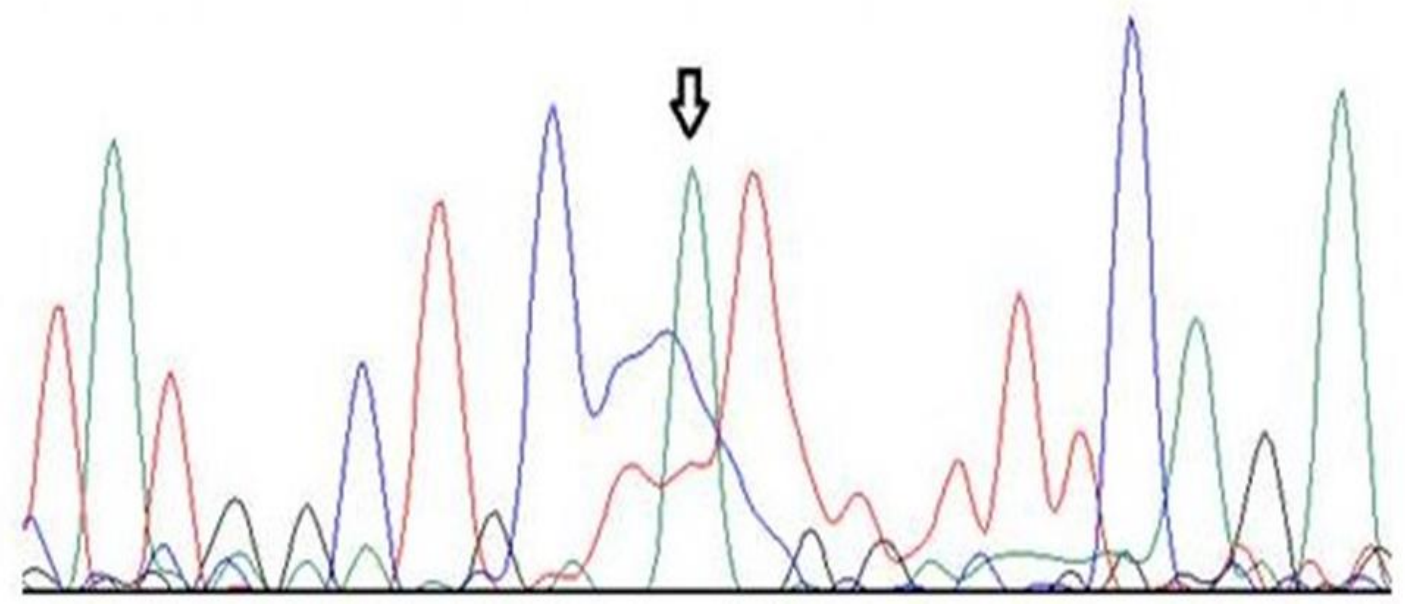

Fig. 7: Electropherogram showing Sanger Sequencing of ADAMTS1 gene. The arrow indicates the location of the Single nucleotide polymorphism 


\section{Discussion}

Currently, FFPE tissues are progressively used for molecular analyses both in clinical and research laboratories. The expulsion of the paraffin wax encasing the thin layer of tissue and isolation of adequate intact DNA are major impediments to work with these samples. Lately, the methods and protocols for the isolation of DNA from FFPE tissues have been considerably improved (Regan et al., 2012; Okello et al., 2010; Huijsmans et al., 2010). In this study, we illustrate a dynamic protocol for the isolation of DNA from FFPE tissue samples. Our study demonstrated that amongst the five DNA extraction protocols assessed, Modified non heating extraction protocol was found to be the most reliable method for the clinical diagnosis in terms of quantity, quality (Table 3; Fig. 2A) and cost effectiveness. On the other hand, Phenol chloroform extraction was found to be quite laborious, involving a large number of steps, prone to cross contamination and has had environmental effects. Salting-out method was likewise prone to salt contamination which might result in PCR inhibition. In the case of Spin column extraction, the yield of DNA obtained was exceptionally low and comparatively very expensive. Non heating extraction method has shown effective results but it was found that Modified non heating extraction resulted in better quality and quantity of DNA which can be preserved for a longer time without rapid degradation (Fig. 2B).

The changes implemented for Modified non heating extraction include (a) Over night digestion using proteinase $\mathrm{K}$ at $56^{\circ} \mathrm{C}$. Proteinase $\mathrm{K}$ gets activated at $56^{\circ} \mathrm{C}$, an interesting characteristic of proteinase $\mathrm{K}$ is that it retains its activity in the presence of Sodium Dodecyl Sulphate (SDS). In turn increasing the temperature of the reaction from $37^{\circ} \mathrm{C}$ to $50^{\circ}-60^{\circ} \mathrm{C}$ and thereby increases its activity by several folds. Another striking feature of proteinase $\mathrm{K}$ is its ability to digest native proteins at $56^{\circ} \mathrm{C}$, thereby inactivating enzymes such as DNase and RNase without recourse to a denaturation process. (b) Elution of FFPE tissue DNA using TE buffer, where TE is derived from its components Tris and EDTA, a molecule that chelates cations like $\mathrm{Mg}^{2+}$ and solubilizes DNA or RNA. The pH of TE buffer is slightly basic which allows DNA to dissolve faster and EDTA helps to protect it from degradation. (c) Preheating TE buffer at $95^{\circ} \mathrm{C}$ is done to eliminate DNase contamination, heating at higher temperatures allows better hydration of DNA hence allowing a better absorption of DNA. (d) Heating the eluted DNA at $65^{\circ} \mathrm{C}$ for five min removes the ethanol traces and helps to dissolve the pellet quickly, thereby increases DNA yield.

Earlier studies on DNA extraction protocols have revealed that heating tissues at high temperature may lead to the extraction of good quality DNA (Frank et al.,
1996; Faulkner and Leigh, 1998). Other studies have reported that higher temperature heating under an alkaline condition provided the most acceptable results (Shi et al., 2002). Sam et al. (2012) reported that Qiagen EZ1 DNA Tissue Kit requires less hands-on-time to yield adequate DNA concentration and quality and is also found to be a proficient method for purifying DNA from FFPE tissues. However, this method in all aspects seems to be quite expensive (Sam et al., 2012). In spite of the fact that there are some evidences that the simple heating method can yield adequate quantity of DNA and also be utilized for detection of genomic changes in DNA extracted from FFPE tissue sections, this approach has not been widely applied. One possible reason may be that the quantity of DNA extracted from FFPE tissue by heating alone is lower than that extracted by an enzymebased protocol (Sam et al., 2012).

The enzymatic digestion step is without doubt a standout amongst most imperative steps in the Modified non heating extraction procedure. The enzyme volume plays a critical role in tissue digestion. One $h$ and overnight digestions have been utilized in various studies earlier (Huijsmans et al., 2010; Santos et al., 2009; Oh et al., 2013) and researchers have also repeatedly acknowledge the fact that prolonged protein digestion time enhances DNA yield (Pikor et al., 2011; Isola et al., 1994; Wood et al., 2010). Among the two modifications in our Modified non heating extraction, overnight incubation of tissue fragment at $56^{\circ} \mathrm{C}$ is one of the key factors in increasing the DNA yield. Proteinase $\mathrm{K}$ is a member of the subtilisin family; the enzyme is a long polypeptide protein which is comprised of 278 amino acids. This enzyme acts on proteins by cleaving the peptide bonds adjacent to the carboxyl group of hydrophobic amino acid residues (aliphatic and aromatic). The optimal temperature for proteinase $\mathrm{K}$ is known to be between $50-60^{\circ} \mathrm{C}$ and the specific activity of proteinase $\mathrm{K}$ is enhanced by increasing the temperature from $52^{\circ} \mathrm{C}$ to $56^{\circ} \mathrm{C}$ (Snow et al., 2014). This will unfold the proteins, exposing the hydrophobic amino acid residues that would be normally encrypted inside the hydrophobic core of the protein making it easier for enzyme action. Moreover, at higher temperatures most nucleases that would degrade DNA are denatured thus making the increase in temperature favorable for efficient DNA precipitation. The same was evident in our study

Further, the assumption underlying the extension of enzymatic (proteinase $\mathrm{K}$ ) digestion is that the persistent protein-DNA cross-links are reversed by heat and that this reversal can be improved either by increasing the incubation temperature or time (Huijsmans et al., 2010; Shi et al., 2002; Isola et al., 1994; Einaga et al., 2017). Removal of the protein-DNA cross-links by maximizing the protease digestion, will ultimately lead to precipitation of relatively intact DNA. 
Hence, in Modified non heating extraction we have used $56^{\circ} \mathrm{C}$ as the incubation temperature and overnight incubation time, which facilitates proper digestion of the tissues. Kumar et al. (2016) have reported that quantification of DNA influences the PCR results obtained from FFPE tissue DNA. They have demonstrated that considerable differences exist between DNA quantification protocols that might cause researchers to under/overestimate the quantity of DNA in their samples.

It has also been reported that the issue of quantification of DNA from human diagnostic specimens, either fresh-frozen or FFPE, is also not adequately addressed in the literature (Kumar et al., 2016). We noticed that the age and origin of the FFPE tissue sample influenced the DNA isolation efficiency (Fig. 4 and 5). However, our NanoDrop results suggest that the DNA yield from 7-year-old FFPE tissue material was equally good in comparison to a two-year-old block (Table 4). In fact the DNA showed long term stability and was found to be intact for the next 6 months (Table 4). Besides, the tissue samples vary with regard to tissue compositions that include inflammatory cells and parenchymal cells. These cells bring about differences in cell density and therefore different DNA quantities are observed in a given tissue surface area. Our study revealed that Spin column extraction, Salting-out method and Phenol chloroform method brought about low quality and yield of DNA which wasn't useful for downstream molecular studies, whereas Modified non heating extraction method lead to successful amplification of the ADAMTS1 gene with an amplicon size of 218 base pairs (Fig. 6). Numerous studies have reported that fragmented DNA is obtained due to fixation and embedding processes, only allowing PCR analysis on short target gene sequences (Liu et al., 1993; Pavelić et al., 1996; Bonin et al., 2005; Shi et al., 2002).

In our study PCR amplification was visible only with $50 \mathrm{ng}$ of DNA isolated by using Modified Non heating extraction method and not with $100 \mathrm{ng}$ and 250 $\mathrm{ng}$, it was observed that the input of higher concentrations of DNA can lead to inhibition of PCR amplification. The primary reason being the fragmented nature of the DNA, which not only influences the target sequence but also randomly generates short DNA debris. This debris might act directly as an inhibitor of the DNA polymerase. The DNA debris might bind to the polymerase and decrease its activity resulting in a decreased PCR reaction speed (Dietrich et al., 2013). However, the other four methods generated low quality of DNA and showed no PCR amplification (Fig. 3), due to the DNA being impure and extremely fragmented.

Gall et al. (1993) and Sato et al. (2001) have suggested that avoiding one or more of the following steps such as centrifugation, dewaxing, digestion with proteinase $\mathrm{K}$, purification may improve PCR efficiency,
(Gall et al., 1993; Sato et al., 2001; Coates et al., 1991; Shi et al., 2002) but due to this DNA purity may be reduced. Our results were obtained with modifications in conventional extraction procedures, by combining: A. Pre heating of tissue at $56^{\circ} \mathrm{C}$; b. Deparaffinization with xylene; c. Digestion over night with concentrated proteinase K (20 mg/mL); d. Purification by phenol chloroform extraction and e. increase in the number of PCR amplification cycles up to 35. The most critical step affecting DNA integrity is the fixation process. Specifically, the degree of damage in DNA may depend on the kind of fixative used and the extent of fixation. However, formaldehyde, a principal active component of formalin causes degradation of the nucleic acids under extremely acidic environment which negatively influences the downstream applications (Blow, 2007; Gilbert et al., 2007; Turashvili et al., 2012). It decreases the efficiency of PCR due to the presence of chemical cross-linking between RNA, DNA and protein. In addition, monomethylol groups are also added to nucleotide base pairs (Specht et al., 2001; Kokkat et al., 2013). These processes increase the vulnerability of nucleotide sequences to shear, fragment and degrade. The age of the fixed tissue, the dimensions and conditions of storage, have been implicated as factors that can influence the process of cross linking and molecular degradation (Cukier et al., 2009).

In our study we have shown that DNA extracted from Modified non heating extraction can be used for downstream molecular analysis like Sanger sequencing and TaqMan SNP genotyping assay. We were able to successfully genotype 3'UTR miRNA binding site polymorphism in ADAMTS1 gene. The genotyping results suggested that the most of the samples genotyped showed homozygous normal condition (C/C) (Fig. 7). For genotyping we utilized FFPE tissue DNA isolated from colorectal cancer tissues and normal colonic mucosa tissues. Even though the normal colonic mucosa archival tissue is a smaller biopsy compared to colorectal cancer archival tissue we were able to isolate good quality and quantity of DNA. Snow et al. (2014) have reported that extraction of DNA from cellular tumors with a solid growth pattern and less contaminating nonneoplastic tissue is comparatively easy. In contrast to small biopsies which usually contain minute nests of tumor cells surrounded by non-tumor tissue creating a challenge in obtaining adequate quantity of DNA material (Snow et al., 2014). Therefore our newly modified DNA extraction method enables us to acquire adequate quantity of DNA from diminutive foci of the tumor and can be utilized for both cancer tissues as well as non neoplastic tissues.

It was observed that our study showed concordance to Betge et al. (2015) who has tried to compare sequencing in fresh and frozen tissue samples and have 
reported that convincing results were obtained with FFPE tissues (Betge et al., 2015). Past studies have reported that NGS (Gall et al., 1993), Genome-wide massively parallel sequencing (Schweiger et al., 2009), Whole genome (Van Allen et al., 2014) and Whole exome sequencing (Astolfi et al., 2015; Bonfiglio et al., 2016) have been performed on FFPE tissues. But all these methods are very expensive compared to Sanger sequencing and TaqMan SNP genotyping assay. One reason behind the slightly higher amplification rate for TaqMan SNP genotyping assay could be that this technique combines both amplification and hybridization with specific fluorescent probes, therefore making it more sensitive than amplification alone at an affordable price, which may be time consuming. In summary, the Modified non heating extraction results in greater yield, optimum DNA concentration and quality and it is found to be an efficient method for extracting DNA from FFPE tissues. This is a critical factor for consideration where DNA isolation is a routine in clinical laboratories for various genetic analyses, as molecular techniques are moving rapidly from bench to bed use in diagnostic pathology.

\section{Conclusion}

Modified non heating extraction is a cost effective and non-laborious protocol which can successfully extract DNA from FFPE tissues and facilitate the downstream molecular analysis of a large number of archival tissues in retrospective studies. Among the five methods tested for its effectiveness, Modified non heating extraction showed efficient DNA extraction for TaqMan SNP genotyping assay and Sanger sequencing used for SNP detection.

\section{Acknowledgement}

Authors thank the management of Sri Ramachandra Institute of Higher Education and Research (Deemed to be University) for providing us with the infrastructure and support for SSK, ZSS and NK. We thank the technical staff of the Pathology Department, the Central laboratory and the medical records of Sri Ramachandra Medical Centre. I would also like to extend my gratitude to Dr. Arvind Ramanathan, Enable Biolabs, Chennai for his timely technical advice.

\section{Authors Contributions}

Charles Emmanuel Jebaraj Walter and Thanka Johnson: Conceived and designed the experiments.

Sai Sushmitha Kontham: Carried out recruitment of subjects, experiments and drafted the manuscript.
Manjula Raju: Helped in carrying out Sanger sequencing.

Chinambedu Dandapani Mohanapriya:

Analyzed the data.

Nirmala Karuppasamy and Zioni Sangeetha Shankaran: Provided their critical suggestions in completion of the experiments.

Charles Emmanuel Jebaraj Walter and Thanka Johnson: Reviewed and finalized the manuscript.

\section{Ethics}

All procedures performed in studies involving human participants were in accordance with the ethical standards of the institutional and/or national research committee and with the 1964 Helsinki declaration and ICMR ethical guidelines for biomedical research. For this type of study formal consent is not required. Institutional Ethical clearance (REF: IECNI/15/APR/46/26) was obtained from Sri Ramachandra Institute of Higher Education and Research.

\section{Conflict of Interest}

The authors declare that they have no competing interests. The corresponding author affirms that all of the authors have read and approved the manuscript.

\section{References}

Astolfi, A., M. Urbini, V. Indio, M. Nannini and C.G. Genovese et al., 2015. Whole Exome Sequencing (WES) on Formalin-Fixed, |Paraffin-Embedded (FFPE) tumor tissue in Gastrointestinal Stromal Tumors (GIST). BMC Genom., 16: 892-892.

DOI: $10.1186 / \mathrm{s} 12864-015-1982-6$

Azimzadeh, O., Z. Barjaktarovic, M. Aubele, J. CalzadaWack and H. Sarioglu et al., 2010. Formalin-Fixed Paraffin-Embedded (FFPE) proteome analysis using gel-free and gel-based proteomics. J. Proteome Res., 9: 4710-4720. DOI: 10.1021/pr1004168

Betge, J., G. Kerr, T. Miersch, S. Leible and G. Erdmann et al., 2015. Amplicon sequencing of colorectal cancer: Variant calling in frozen and formalin-fixed samples. PLoS One, 10: e0127146e0127146.

DOI: 10.1371 /journal.pone.0127146

Blow, N., 2007. Tissue preparation: Tissue issues. Nature, 448: 959-963. DOI: 10.1038/448959a

Bonfiglio, S., I. Vanni, V. Rossella, A. Truini and D. Lazarevic et al., 2016. Performance comparison of two commercial human whole-exome capture systems on formalin-fixed paraffin-embedded lung adenocarcinoma samples. BMC Cancer, 16: 692-692. DOI: 10.1186/s12885-016-2720-4 
Bonin, S., F. Petrera, J. Rosai and G. Stanta, 2003. PCR analysis in archival postmortem tissues. Mol. Pathol., 56: 184-186. DOI: 10.1136/mp.56.3.184

Bonin, S., F. Petrera, J. Rosai and G. Stanta, 2005. DNA and RNA obtained from Bouin's fixed tissues. J. Clin. Pathol., 58: 313-316. DOI: $10.1136 /$ jcp.2004.016477

Coates, P.J., A.J. d'Ardenne, G. Khan, H.O. Kangro and G. Slavin, 1991. Simplified procedures for applying the polymerase chain reaction to routinely fixed paraffin wax sections. J. Clin. Pathol., 44: 115-118. DOI: $10.1136 /$ jcp.44.2.115

Cukier, H.N., M.A. Pericak-Vance, J.R. Gilbert and D.J. Hedges, 2009. Sample degradation leads to falsepositive copy number variation calls in multiplex realtime polymerase chain reaction assays. Anal. Biochem., 386: 288-290.

DOI: $10.1016 /$ j.ab.2008.11.040

Dedhia, P., S. Tarale, G. Dhongde, R. Khadapkar and B. Das, 2007. Evaluation of DNA extraction methods and real time PCR optimization on formalin-fixed paraffinembedded tissues. Asian. Pac. J. Cancer Prev., 8: 17477772-17477772. PMID: 17477772

Dietrich, D., B. Uhl, V. Sailer, E.E. Holmes and M. Jung et al., 2013. Improved PCR performance using template DNA from formalin-fixed and paraffin-embedded tissues by overcoming PCR inhibition. PLoS One.

DOI: 10.1371/journal.pone.0077771

Einaga, N., A. Yoshida, H. Noda, M. Suemitsu and Y. Nakayama et al., 2017. Assessment of the quality of DNA from various Formalin-Fixed ParaffinEmbedded (FFPE) tissues and the use of this DNA for Next-Generation Sequencing (NGS) with no artifactual mutation. PLoS One, 12: e0176280-e0176280.

DOI: 10.1371/journal.pone.0176280

Faulkner, S.W. and D.A. Leigh, 1998. Universal amplification of DNA isolated from small regions of paraffin-embedded, formalin-fixed tissue. Biotechniques, 24: 47-50. DOI: 10.2144/98241bm08.

Frank, T.S., S.M. Svoboda-Newman and E.D. Hsi, 1996. Comparison of methods for extracting DNA from formalin-fixed paraffin sections for non isotopic PCR. Diagn. Mol. Pathol., 5: 220-224.

DOI: 10.1097/00019606-199609000-00012

Gall, K., J. Pavelić, D. Jadro-Santel, M. Poljak and K. Pavelić, 1993. DNA amplification by polymerase chain reaction from brain tissues embedded in paraffin. Int. J. Exp. Pathol., 74: 333-337. PMID: 8398805

Gilbert, M.T.P., T. Haselkorn, M. Bunce, J.J. Sanchez and S.B. Lucas et al., 2007. The isolation of nucleic acids from fixed, paraffin-embedded tissues-which methods are useful when? PloS One, 2: e537-e537. DOI: 10.1371/journal.pone.0000537
Gnanapragasam, V.J., 2010. Unlocking the molecular archive: The emerging use of formalin-fixed paraffin-embedded tissue for biomarker research in urological cancer. BJU Int., 105: 274-278. DOI: 10.1111/j.1464-410X.2009.08665.x

Goelz, S.E., S.R. Hamilton and B. Vogelstein, 1985. Purification of DNA from formaldehyde fixed and paraffin embedded human tissue. Biochem. Biophys. Res. Commun., 130: 118-126. DOI: $10.1016 / 0006-291 \times(85) 90390-0$

Huijsmans, C.J., J. Damen, J.C. van der Linden, P.H. Savelkoul and M.H. Hermans, 2010. Comparative analysis of four methods to extract DNA from paraffin-embedded tissues: Effect on downstream molecular applications. BMC Res. Notes, 3: 239-239. DOI: 10.1186/1756-0500-3-239

Isola, J., S. DeVries, L. Chu, S. Ghazvini and F. Waldman, 1994. Analysis of changes in DNA sequence copy number by comparative genomic hybridization in archival paraffin-embedded tumor samples. Am. J. Pathol., 145: 1301-1308. PMID: 7992835

Kokkat, T.J., M.S. Patel, D. Mc Garvey, V.A. LiVolsi and Z.W. Baloch, 2013. Archived Formalin-Fixed Paraffin-Embedded (FFPE) blocks: A valuable underexploited resource for extraction of DNA, RNA and protein. Biopreserv. Biobank, 11: 101-106. DOI: 10.1089/bio.2012.0052

Kumar, D., M.K. Panigrahi, M. Suryavanshi, A. Mehta and K.K. Saikia, 2016. Quantification of DNA extracted from formalin fixed paraffinembedded tissue comparison of three techniques: Effect on PCR efficiency. J. Clin. Diagn. Res., 10: BC01-BC03. DOI: $10.7860 / J C D R / 2016 / 19383.8407$

Kuno, K., N. Kanada, E. Nakashima, F. Fujiki and F. Ichimura et al., 1997. Molecular cloning of a gene encoding a new type of metalloproteinasedisintegrin family protein with thrombospondin motifs as an inflammation associated gene. J. Biol. Chem., 272: 556-562. DOI: 10.1074/jbc.272.1.556

Lehmann, U. and H. Kreipe, 2001. Real-time PCR analysis of DNA and RNA extracted from formalin fixed and paraffin embedded biopsies. Methods, 25: 409-418. DOI: 10.1006/meth.2001.1263

Lin, J., S.H. Kennedy, T. Svarovsky, J. Rogers and J.W. Kemnitz et al., 2009. High- quality genomic DNA extraction from formalin-fixed and paraffinembedded samples deparaffinized using mineral oil. Anal. Biochem., 395: 265-267. DOI: 10.1016/j.ab.2009.08.016

Liu, J., R.M. Johnson and S.T. Traweek, 1993. Rearrangement of the BCL-2 gene in follicular lymphoma. Diagn. Mol. Pathol., 2: 241-247. PMID: 8118601 
Ludyga, N., B. Grünwald, O. Azimzadeh, S. Englert and H. Höfler et al., 2012. Nucleic acids from long-term preserved FFPE tissues are suitable for downstream analyses. Virchows Arch, 460: 131-140.

DOI: $10.1007 / \mathrm{s} 00428-011-1184-9$

Miller, S.A., D.D. Dykes and H.F.R.N. Polesky, 1988. A simple salting out procedure for extracting DNA from human nucleated cells. Nucleic Acids Res., 16: 1215-1215. DOI: 10.1093/nar/16.3.1215

Oh, S.Y., W.Y. Kim, T.S. Hwang, H.S. Han and S.D. Lim et al., 2013. Development of an ammonium sulfate DNA extraction method for obtaining amplifiable DNA in a small number of cells and its application to clinical specimens. Biomed. Res. Int.

Okello, J.B., J. Zurek, A.M. Devault, M. Kuch and A.L. Okwi et al., 2010. Comparison of methods in the recovery of nucleic acids from archival formalin-fixed paraffin-embedded autopsy tissues. Anal. Biochem., 400: 110-117. DOI: 10.1016/j.ab.2010.01.014

Pavelić, J., K. Gall-Troselj, M.H. Bosnar, M.M. Kardum and K. Pavelić, 1996. PCR amplification of DNA from archival specimens. A methodological approach. Neoplasma, 43: 75-81.

Pikor, L.A., K.S. Enfield, H. Cameron and W.L. Lam, 2011. DNA extraction from paraffin embedded material for genetic and epigenetic analyses. J. Vis. Exp.

Quach, N., M.F. Goodman and D. Shibata, 2004. In vitro mutation artifacts after formalin fixation and error prone translesion synthesis during PCR. BMC Clin. Pathol., 4: 1-1. DOI: 10.1186/1472-6890-4-1

Regan, J.F., M.R. Furtado, M.G. Brevnov and J.A. Jordan, 2012. A sample extraction method for faster, more sensitive PCR-based detection of pathogens in blood culture. J. Mol. Diagn., 14: 120-129.

DOI: 10.1016/j.jmoldx.2011.10.001

Sam, S.S., K.A. Lebel, C.L. Bissaillon, C.L. Tafe and G.J. Tsongalis et al., 2012. Automation of genomic DNA isolation from formalin-fixed, paraffinembedded tissues. Pathol. Res. Pract., 208: 705-707. DOI: 10.1016/j.prp.2012.08.008

Santos, S., D. Sá, E. Bastos, H. Guedes-Pinto and I. Gut et al., 2009. An efficient protocol for genomic DNA extraction from formalin-fixed paraffinembedded tissues. Res. Vet. Sci., 86: 421-426.

DOI: $10.1016 /$ j.rvsc.2008.08.007

Sato, Y., R. Sugie, B. Tsuchiya, T. Kameya and T. Natori et al., 2001. Comparison of the DNA extraction methods for polymerase chain reaction amplification from formalin-fixed and paraffinembedded tissues. Diagn. Mol. Pathol., 10: 265-271. DOI: 10.1097/00019606-200112000-00009

Schweiger, M.R., M. Kerick, B. Timmermann, M.W. Albrecht and T. Borodina, 2009. Genome-wide massively parallel sequencing of Formaldehyde Fixed-Paraffin Embedded (FFPE) tumor tissues for copy-number-and mutation-analysis. PLoS One, 4: e5548-e5548. DOI: 10.1371/journal.pone.0005548
Shi, S.R., R. Datar, C. Liu, L. Wu and Z. Zhang, et al., 2004. DNA extraction from archival formalin-fixed, paraffin-embedded tissues: Heat-induced retrieval in alkaline solution. Histochem Cell Biol., 122: 211-218. DOI: 10.1007/s00418-004-0693-x

Shi, S.R., R.J. Cote, L. Wu, C. Liu and R. Datar et al., 2002. DNA extraction from archival formalin-fixed, paraffin-embedded tissue sections based on the antigen retrieval principle: Heating under the influence of $\mathrm{pH}$. J. Histochem. Cytochem., 50: 1005-1011. DOI: 10.1007/s00418-004-0693-X

Shindo, T., H. Kurihara, K. Kuno, H. Yokoyama and T. Wada et al., 2000. ADAMTS-1: A metalloproteinase-disintegrin essential for normal growth, fertility and organ morphology and function. J. Clin. Invest., 105: 1345-1352. DOI: $10.1172 / \mathrm{JCI} 8635$

Snow, A.N., A.A. Stence, J.A. Pruessner, A.D. Bossler and D. Ma, 2014. A simple and cost-effective method of DNA extraction from small formalinfixed paraffin-embedded tissue for molecular oncologic testing. BMC Clin. Pathol., 14: 30-30. DOI: 10.1186/1472-6890-14-30

Specht, K., T. Richter, U. Müller, A. Walch and M. Werner, et al., 2001. Quantitative gene expression analysis in microdissected archival formalin-fixed and paraffin-embedded tumor tissue. Am. J. Pathol., 158: 419-429.

DOI: $10.1016 / \mathrm{S} 0002-9440(10) 63985-5$

Toews, J., J.C. Rogalski, T.J. Clark and J. Kast, 2008. Mass spectrometric identification of formaldehydeinduced peptide modifications under in vivo protein cross-linking conditions. Anal. Chim. Acta, 618: 168-83. DOI: 10.1016/j.aca.2008.04.049

Turashvili, G., W. Yang, S. McKinney, S. Kalloger and N. Gale et al., 2012. Nucleic acid quantity and quality from paraffin blocks: Defining optimal fixation, processing and DNA/RNA extraction techniques. Exp. Mol. Pathol., 92: 33-43.

DOI: 10.1016/j.yexmp.2011.09.013

Van Allen, E.M., N. Wagle, P. Stojanov, D.L. Perrin and K. Cibulskis et al., 2014. Whole-exome sequencing and clinical interpretation of formalin-fixed, paraffin-embedded tumor samples to guide precision cancer medicine. Nat. Med., 20: 682-688.

DOI: $10.1038 / \mathrm{nm} .3559$

Wisniewski, J.R., P. Ostasiewicz and M. Mann, 2011. High recovery FASP applied to the proteomic analysis of microdissected formalin fixed paraffin embedded cancer tissues retrieves known colon cancer markers. J. Proteome Res., 10: 3040-3049. DOI: $10.1021 / p r 200019 m$ 
Wood, H.M., O. Belvedere, C. Conway, C. Daly and R. Chalkley et al., 2010. Using next-generation sequencing for high resolution multiplex analysis of copy number variation from nanogram quantities of DNA from formalin-fixed paraffin-embedded specimens. Nucleic Acids Res., 38: e151-e151.

DOI: 10.1093/nar/gkq510
Xiao, Z., G. Li, Y. Chen, M. Li and F. Peng et al., 2010. Quantitative proteomic analysis of formalin-fixed and paraffin-embedded nasopharyngeal carcinoma using iTRAQ labeling, two-dimensional liquid chromatography and tandem mass spectrometry. J. Histochem. Cytochem., 58: 517-527.

DOI: $10.1369 /$ jhc.2010.955526 